\title{
Engine optimization grate multipurpose analysis method with quality function deployment
}

\author{
Nukman ${ }^{1}$, Irsyadi Yani $^{1}$ and Firdaus ${ }^{1}$ \\ ${ }^{1}$ Mechanical Engineering Department, Faculty of Engineering Universitas Sriwijaya, 30139 Palembang, Indonesia
}

\begin{abstract}
The object that will be developed in this study is a simple technology shredding machine design, artificial and has been patented by Andi Patolla (1988). which is often used by people specifically to grate the coconut. The methods used for product development using QFD. This method is needed to analyze and evaluate the level of consumer desires in order to develop products grate machine. The subject matter of the research outlined in the distribution table discussion. The research instrument used when data collection is questionnaire technique, which is supported by the observation technique, documentation, and interviews. From the discussion that has been done, it can be concluded that the priority consumers are very stressed to do a modification component or an additional tool in the machine grater multipurpose namely Cover Safeguard Fan Belt, Exhaust, Priority Motor Driving Fuel Gasoline, layout position Mover, Motor Starter, Plastic cleaning brush Roll Grate, and Plate Cap. 2.
\end{abstract}

\section{Introduction}

Increasing customer satisfaction is one of the actions undertaken to determine the value added to a product. Improved product quality is a measure to improve the quality of products to provide the best for consumers. Reference [14] said that the development process has meaning, how to develop in order to be developed, good or perfect. Innovation or creative ideas play a major role in achieving marketing success in order to maintain and increase the superior quality of high competitiveness so that the product become acceptable in a market.

To identify and evaluate problems in order to develop a product, then use the analysis method of Quality Function Deployment (QFD) in order to know exactly the wishes of consumers. In accordance with the statement of the experts, Ref [17] "QFD is a methodology, the which establishes a relationship between product and customer, determines the product's sales ability and carry out it to a high level during the process", Then by Bernal [2] "QFD is a system with the aim of translating and planning the "voice of the customer" into the quality characteristics of products, processes and services in order to reach customer satisfaction".

The object that will be developed in this study is a simple technology shredding machine design, artificial and has been patented by Andi Patolla [11]which is often used by people specifically to grate the coconut. The methods used for product development using QFD. This method is useful to analyse and evaluate the level of consumer desires in order to develop products grate machine. The subject matter of the research outlined in the distribution table discussion.
Manufacturing development study using QFD method that has prospects for development approaches that lead to the development of services, to improve services to the public which deals with the design, models and product selection has been done by several authors $[2,6,8,12,15]$. Development in the field of manufacturing, with respect to the development of manufacturing strategy based on fuzzy, Integration and value engineering in the Furniture Manufacturing Industry, as well as the picture of the future quality of the product for future research are discussed by $[1,5,10]$. Meanwhile other works by Zarei [18] was discussed on food supply chain leanness, and [7] on designing a sustainable maritime supply chain. Supply chain is a series of link that is often used in the manufacturing process. The development made by both literatures is the aspect of wear and the design of supply chain [4]. The Assessment of Aircraft Maintenance Education, process Machining, Concurrent engineering were set on approach in the development of composite [9]. There was a different product development discussed on the literatures. Each of them was develop products related to the assessment of aircraft maintenance, machining processes, and composites. Basically each literature has a goal to develop better products.

Reviewing the literature over from year to year the diverse areas of study and products developed by some experts. Over time, the QFD method is always used in a variety of product development, in 2016. This method was also applied to the development QFD Engine Optimization Multipurpose shredders. Applying QFD in this study is a right step in meeting consumers' desire to get new innovations to grate multipurpose machine. 


\section{Research method}

Questionnaire dates were made from a predetermined sample of 40 people. It consists of four regions population research sites, then integrated in a distribution table traders overall assessment questionnaire, ranging from OI region, Muara Enim, OKI, and Palembang as shown in Table 1.

Table 1. Questionaire for Assesment

\begin{tabular}{|c|c|c|c|c|c|c|c|c|}
\hline & \multirow{2}{*}{ Type of Problem } & \multirow{2}{*}{$\begin{array}{l}\text { Total } \\
\text { Samples } \\
\text { (people) }\end{array}$} & \multicolumn{4}{|c|}{ Rating $\left({ }^{*}\right)$} & \multirow{2}{*}{ Persentase } & \multirow{2}{*}{ Category } \\
\hline No & & & SA & $A$ & D & SD & & \\
\hline 1 & $\begin{array}{l}\text { Do you think the engine size cocouut } \\
\text { grater you need a large place? ? }\end{array}$ & & 140 & 15 & & & $\frac{212 \mathrm{~T}}{1.60} \times 100=96896$ & $\begin{array}{l}\begin{array}{l}\text { Strongly } \\
\text { zgree }\end{array} \\
\end{array}$ \\
\hline 2 & $\begin{array}{l}\text { II your coconut grater machines are too } \\
\text { complicated when the operator of the } \\
\text { initial ( Start the engine) ? }\end{array}$ & 40 & 136 & 18 & & & $\frac{1154}{160} \times 100=96296$ & $\begin{array}{l}\text { Strongly } \\
\text { agree }\end{array}$ \\
\hline \multirow[t]{3}{*}{3} & $\begin{array}{l}\text { Cocorut grater machine type do you use? } \\
\text { 2. Type Electric Motor }\end{array}$ & 40 & & & & & \multirow[t]{2}{*}{$\frac{1210}{160} \times 100=93.796$} & \multirow[t]{2}{*}{$\begin{array}{l}\text { Strongly } \\
\text { agree }\end{array}$} \\
\hline & b. Type Motor Gasoline & & 152 & 6 & & & & \\
\hline & $\begin{array}{l}\text { c Type Diesel } \\
\text { Is coconut grater mochines yout use too }\end{array}$ & 40 & & & & & \multirow{4}{*}{$\frac{69}{160} \times 100=43196$} & \multirow{4}{*}{ Diagree } \\
\hline \multirow{3}{*}{4} & $\begin{array}{l}\text { Is coconut grater machines you wae too } \\
\text { wasteful of energy? }\end{array}$ & & & & & & & \\
\hline & 2. Type Electric Motor (R/Wh) & & & & & & & \\
\hline & 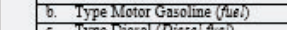 & & & 3 & 55 & II & & \\
\hline \multirow[t]{4}{*}{5} & $\begin{array}{l}\text { Ic Type Desel (Dieselifyei) } \\
\text { If you are given the oppottunity to choose, }\end{array}$ & 40 & & & & & \multirow{4}{*}{$\frac{1760}{160} \times 100=96296$} & \multirow{4}{*}{$\begin{array}{l}\text { Strongly } \\
\text { agree }\end{array}$} \\
\hline & $\begin{array}{l}\text { you prefer a machine that uses coconut } \\
\text { grater? }\end{array}$ & & & & & & & \\
\hline & \begin{tabular}{|l} 
2. \\
Type Electric Motor
\end{tabular} & & 4 & 6 & & & & \\
\hline & b. Type Motor Fuel & & 132 & 12 & & & & \\
\hline \multirow[t]{3}{*}{6} & $\begin{array}{l}\text { Is if cifficult to perform maintenance } \\
\text { cocosut grater machines? }\end{array}$ & 40 & & & & & \multirow[t]{3}{*}{$\frac{D 1}{160} \times 100=32.896$} & \multirow[t]{3}{*}{\begin{tabular}{|l|} 
Disagree \\
\end{tabular}} \\
\hline & $\begin{array}{|lc|}\text { a. Clean } \\
\end{array}$ & & & & $\frac{2}{2}$ & & & \\
\hline & b. Lubricate & & & & 18 & 31 & & \\
\hline 7 & $\begin{array}{l}\text { Is the tire cord (Fanbelf) pully intrusive } \\
\text { security? }\end{array}$ & 40 & 160 & & & & $\frac{1200}{160}=100=10094$ & $\begin{array}{l}\begin{array}{l}\text { Strongly } \\
\text { zeree }\end{array} \\
\end{array}$ \\
\hline 8 & $\begin{array}{l}\text { Is it hard to put the raw material into the } \\
\text { roller grated cocorut? }\end{array}$ & 40 & & & 44 & 18 & $\frac{62}{160} \times 100=38796$ & $\begin{array}{l}\text { Tidak } \\
\text { Setuju }\end{array}$ \\
\hline 9 & $\begin{array}{l}\text { Are all the raw materials with refined } \\
\text { coconut terparut ? }\end{array}$ & 40 & 156 & 3 & & & $\frac{129}{160} \times 100=99.396$ & $\begin{array}{l}\text { Strongly } \\
\text { zerree }\end{array}$ \\
\hline 10 & $\begin{array}{l}\text { Is it hard to do the cleaning on the roller } \\
\text { grate, when not in use? }\end{array}$ & 40 & 128 & 24 & & & $\frac{202}{160} \times 100=95 \%$ & $\begin{array}{l}\begin{array}{l}\text { Strongly } \\
\text { agree }\end{array} \\
\end{array}$ \\
\hline \multirow[t]{2}{*}{11} & I9 coconut grater machine too noity? & 40 & & & & & \multirow[t]{2}{*}{$\frac{200}{160} \times 100=10004 \mathrm{i}$} & \multirow{2}{*}{$\begin{array}{l}\text { Strongly } \\
\text { agree }\end{array}$} \\
\hline & 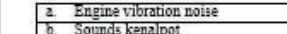 & & 160 & & & & & \\
\hline \multirow[t]{5}{*}{12} & Whether, component (Spure Parts) are & 40 & & & & & \multirow{5}{*}{$\frac{\pi}{160} \times 100=28196$} & \multirow[t]{5}{*}{ Disagree } \\
\hline & difficult to obtain in the market ? & & & & & & & \\
\hline & \begin{tabular}{|l|l} 
2. Worn-out Bearing \\
\end{tabular} & & & 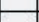 & & & & \\
\hline & \begin{tabular}{|l|l} 
b. Dead Spark plug \\
c. Roller grate broken
\end{tabular} & & & 3 & 6 & 36 & & \\
\hline & $\begin{array}{l}\text { d. Tire cord pulley (fanbeli) } \\
\text { breaks }\end{array}$ & & & & & & & \\
\hline \multirow[t]{5}{*}{ T } & $\begin{array}{l}\text { How old is the use of coconut grater } \\
\text { machine you now? }\end{array}$ & 40 & & & & & \multirow[t]{5}{*}{$\frac{166}{160} \times 100=97.896$} & \multirow[t]{5}{*}{$\begin{array}{l}\text { Strongly } \\
\text { agree }\end{array}$} \\
\hline & 2 I to 6 months & & & & & & & \\
\hline & b. 6 to 12 months & & & 3 & & & & \\
\hline & c. 1 to 2 months & & & & 6 & & & \\
\hline & d. 2 to 5 months & & & & & 147 & & \\
\hline II & $\begin{array}{l}\text { Do you think the usefialuess of coconut } \\
\text { grater machines alreaciy help people? }\end{array}$ & 40 & 160 & & & & $\frac{700}{160} \times 100=1000 \%$ & $\begin{array}{l}\text { Strongly } \\
\text { 2reve }\end{array}$ \\
\hline III & $\begin{array}{l}\text { If the machine uses coconut grater has a } \\
\text { major role in improving your economy? }\end{array}$ & 40 & 160 & & & & $\frac{260}{160} \times 100=100 \%$ & $\begin{array}{l}\text { Strongly } \\
\text { zeree }\end{array}$ \\
\hline
\end{tabular}

Dates obtained from the questionnaire for each area, further data processing with statistical dates analysis techniques described referring to issues based consumer desires. The results in the table above and then poured into House of Quality QFD (House Of Quality).

Fig1. Phase of QFD

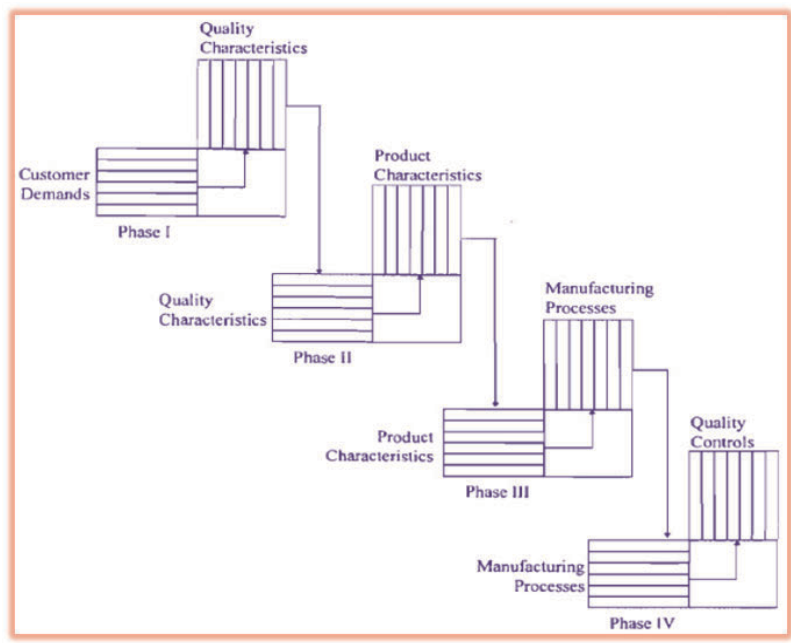

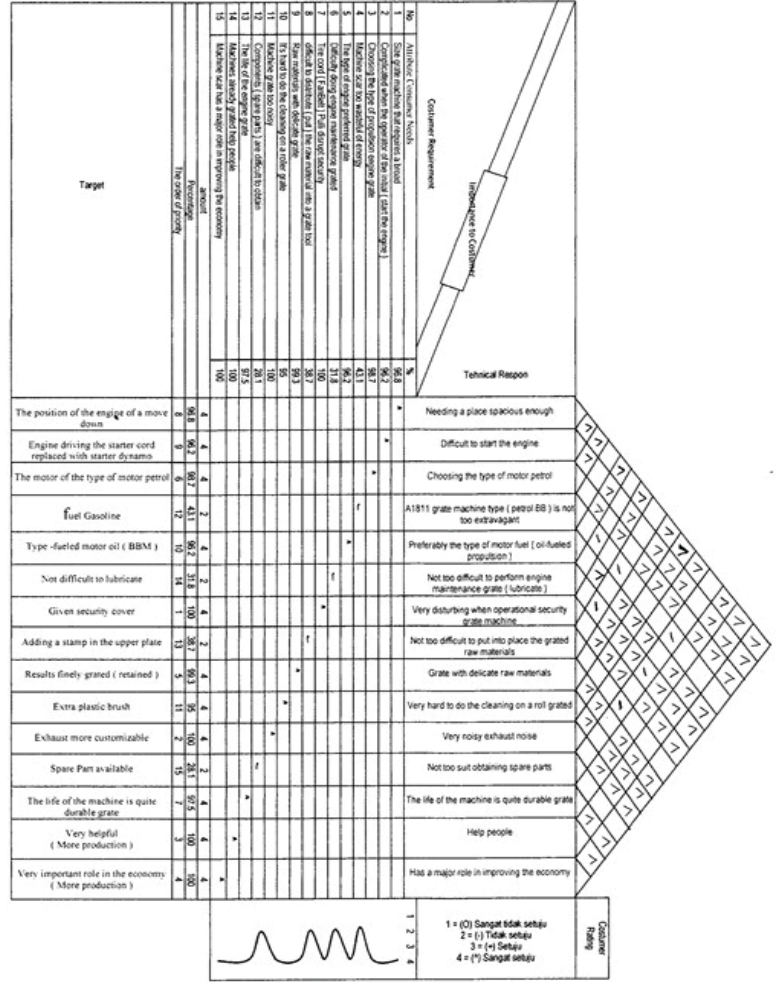

Fig 1. House Of Quality (HOQ)

HOQ house of quality the can be seen Priority needs are desired by consumers. The order of priority in the HOQ above can in description the following caption:

1. Fan Belt interfere with the safety of an operation and a grater machine too noisy then the solution by adding components aluminum cover plate that protects the tires Ropes (fanbelt) and modified the exhaust forms from simple to more customized and equipped with a silencer. 2. The machine uses a greater role in helping people and machines grate in improving the economy. Questionnaire dates showed consumers still want the existence of a grater machines, essentially consumers still need a grater machines as a means to create jobs by selling services grated or shredded results, and become involved in economic principles so that producers do not have to worry mengsa market to customer needs.

3 . Is the raw material refined gratering? and what type grater machines using? ", dates obtained most consumers stated that the results gratering fine grater. as well as questionnaire dates and field observations the average trader using the engine driving type Gasoline Engine.

4. Age use a grater machine and engine size grater, the average merchant traders had undergone profession for 2 years and above, as well as those reported to have never replace the engine, it is proven that the machine age grate quite durable. as well as dates showed that, the engine size grater, it is not suitable. Then the solution by moving the position of the engine of the machine tool gets under grater, so their size is slim.

5. Elaborate current operator of the initial (start the engine) and If you had to choose, would prefer the 
machine what type of motor grater? "Operation consumers complained of a beginning. is it hard to use the starter rope, then the solution by adding the electric starter system, as well as the majority of merchants to choose the type of motor fuel than other types of electric motors, because it can increase operational costs to prepare electricity.

6. It's hard to do the cleaning roller grate, when not in use and energy-intensive grater machines. Analysis of statistical data showed $95 \%$ explained that it is difficult to do the cleaning roll grater (eye roll grated), so the solution must be available grater machine brushes, as well as In accordance with the problem to 3, the majority of consumers use an engine of types Motor Gasoline. As well as scores on this subject showed $43.1 \%$ (* disagree) it can be concluded that the grater machines they use less wasteful of energy.

7. It is difficult to enter into the roller grated raw materials and difficult to perform engine maintenance grater, questionnaire data showed $38.7 \%$ (* disagree). But assessed the level of security of the observation space, a trader presses the raw material used pieces of wood or fingers. Then add Aluminum Cap Plate is suitable to prevent the remaining pieces of the raw materials did not toss out, without having to press it with a finger / timber. As well as dates showed 31.8\% (* do not agree) if such treatments lubricate.

8. Components (Spare Parts) are difficult to obtain in the market. The data shows $28.1 \%$ (* disagree), but sometimes the quality is somewhat different

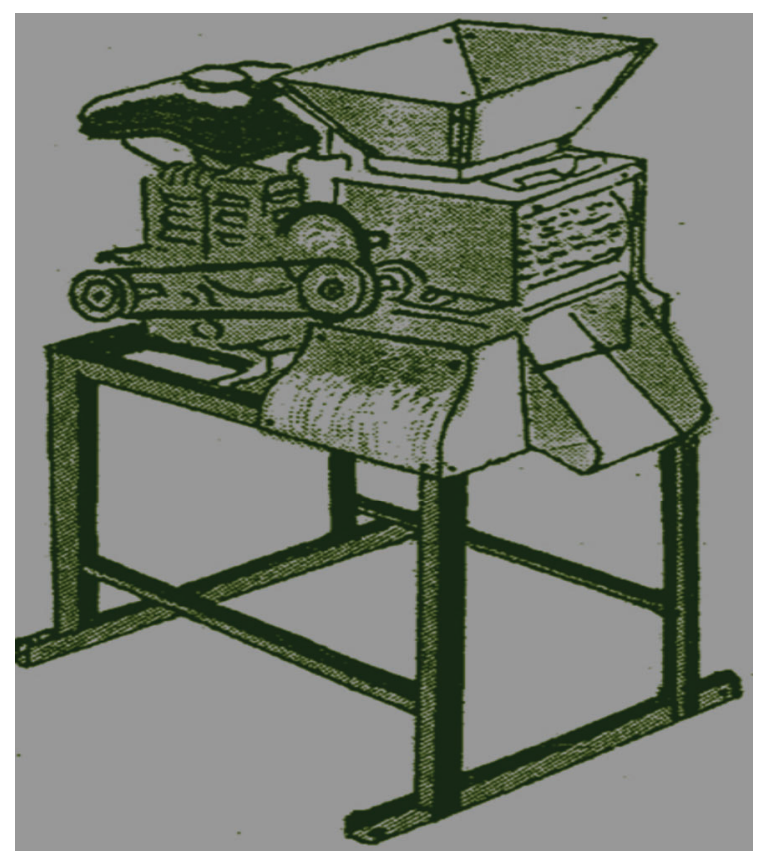

Fig 2. Engineering design grater [11]

The resut found may explains the priorities, the function and purpose of any problems in accordance with the expectations and desires of consumers leading to operation security, maximizing the function of the tool, as well as the addition of new tools in the development of multipurpose grater machines.

\section{Result and Discussion}

Distribution of the questionnaire merchant value (Muara Enim) Distribution of the questionnaire merchant value (Muara Enim)

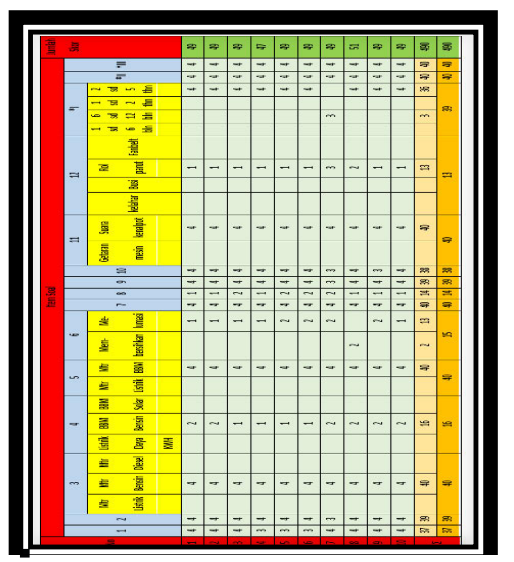

Distribution Frequency

\begin{tabular}{|c|c|c|c|c|c|}
\hline No & $\mathrm{X}$ & $\mathrm{F}$ & FX & $\mathrm{X}^{2}$ & $\mathrm{FX}^{2}$ \\
\hline 1 & 51 & 1 & 51 & 2601 & 2601 \\
\hline 2 & 49 & 8 & 392 & 2401 & 153664 \\
\hline 3 & 47 & 1 & 47 & 2209 & 2209 \\
\hline & $\sum$ & 10 & 490 & 7211 & 158474 \\
\hline
\end{tabular}

Mean $(\bar{x})=\sum \frac{f x}{N}=\frac{490}{10}=49$

$\operatorname{Varian}\left(S^{2}\right)=\frac{n \sum f x^{2}-\left(\sum f x\right)^{2}}{n(n-1)}=$

$\frac{10(158474)-(490)^{2}}{10 \times 9}=14,93$

standard Deviation $(\mathrm{SD})=\sqrt{ } \mathrm{S}^{2}=\sqrt{ } 14,93=3.86$

Modus $(\mathrm{Mo})=49$

Normality test $(\mathrm{Km})=\frac{\bar{x}-M o}{S}=(49-49) / 3.86=0$

Normal distribution of data for value $\mathrm{Km}=0$

located in reception area $-1 \leq \mathrm{Km} \leq 1$

To determine the interpretation of the level of consumer desires of achievement scores obtained from the value of questionnaire data vendors machine user of grated coconut are required in order to interpret the results of the assessment with a score value (n) the average number of samples 49 and $(\mathrm{N})$ total score of base 60 , then percentage of calculation process are :

$\mathrm{P}=\frac{n}{N} \times 100 \%$

then :

$P=\frac{49}{60} \times 100 \%=81.66 \%$ 
From the data contained in the questionnaires for the district of Muara Enim, with the calculation of distribution table, frequency scores questionnaire data vendors, then calculate the Mean $=49$, Varian $=14.93$, standard deviation $=3.86$, mode $=49$, Normality Test $=$ 0 and interpersentase score level consumer desire with the score value achieved was $81.66 \%$. Then the instrument data from the questionnaire scores interpretation value questionnaire merchants engine users grated achieve a score of $81.66 \%$, can be matched with a conversion table in the form of a graduated scale model of which is contained in Table No. 1 by weight 4 results definition "Strongly Agree". Where the scores achieved are in the range of $76 \%-100 \%$ criteria. So we can conclude that for an assessment based on an overall assessment criteria for the desires of consumers (Muara Enim district) to the problems that exist "Strongly Agree" to undertake a development of the engine multipurpose grater.

Distribution of the questionnaire merchant value (OKI)

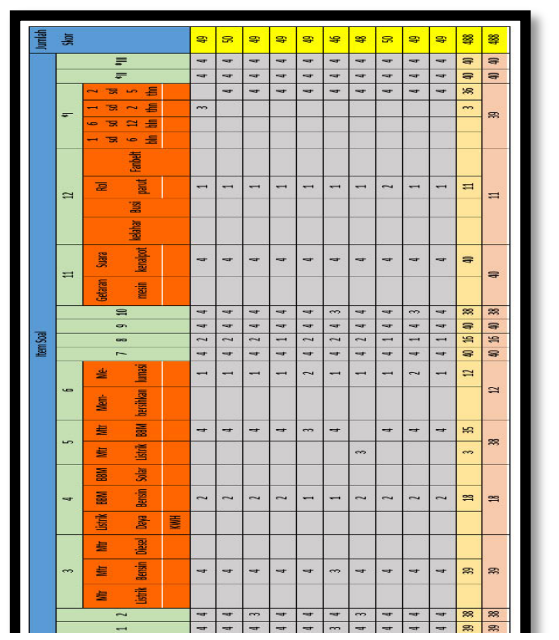

Distribution Frequency

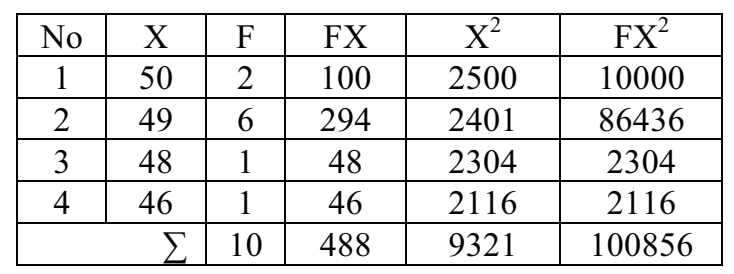

$\operatorname{Mean}(\bar{x})=\sum \frac{f x}{N}=\frac{488}{10}=48.10$

$\operatorname{Varian}\left(S^{2}\right)=\frac{n \sum f x^{2}-\left(\sum f x\right)^{2}}{n(n-1)}=$

$\frac{10(100856)-(488)^{2}}{10 \times 9}=8.55$

Standard Deviation $(\mathrm{SD})=\sqrt{ } \mathrm{S}^{2}=\sqrt{ } 8.55=2.92$

$\operatorname{Modus}(\mathrm{Mo})=49$
Normality test $(\mathrm{Km})(\mathrm{Km})=\frac{\bar{x}-M o}{S}=\frac{48.10-49}{2.92}=-0.3$

Normal distribution of data for value $\mathrm{Km}=-0.3$

located in reception area $-1 \leq \mathrm{Km} \leq 1$

To determine the interpretation of the level of consumer desires of achievement scores obtained from the value of questionnaire data vendors machine user of grated coconut are required in order to interpret the results of the assessment with a score value (n) the average number of samples 48.1 and $(\mathrm{N})$ total score of base 60 , then percentage of calculation process are :

$\mathrm{P}=\frac{n}{N} \times 100 \%$

then :

$\mathrm{P}=\frac{48.10}{60} \times 100 \%=80.16 \%$

From the data contained in the questionnaire instrument for OKI district, with the calculation of the distribution table, frequency scores traders questionnaire data, then calculate the Mean $=48.10$, Varian $=8.55$, standard deviation $=2.92$, mode $=49,=-0.3$ and Normality Test interpersentase score level consumer desire with the score value achieved was $80.16 \%$.

So from the instrument data interpretation value questionnaire scores merchants of grated machine user reached a score of $80.16 \%$, can be matched with a conversion table in the form of a graduated scale model of which is contained in Table No. 1 by weight 4 results definition "Strongly Agree". Where the scores achieved are in the range of $76 \%-100 \%$ criteria. So we can conclude that for an assessment based on an overall assessment criteria for the desires of consumers (district OKI) against the existing problems "Strongly Agree" to undertake a development of the engine multipurpose grater.

Distribution of the questionnaire merchant value (OI)

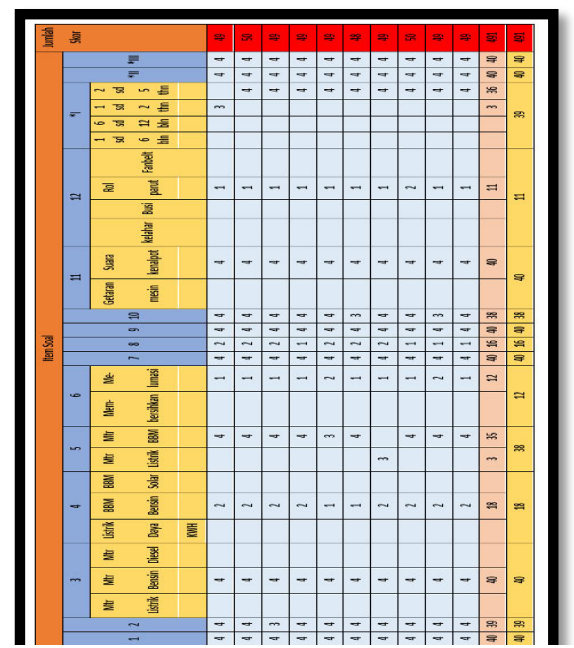


Distribution Frequency

\begin{tabular}{|c|c|c|c|c|c|}
\hline No & $X$ & $\mathrm{~F}$ & FX & $\mathrm{X}^{2}$ & $\mathrm{FX}^{2}$ \\
\hline 1 & 50 & 2 & 100 & 2500 & 10000 \\
\hline 2 & 49 & 7 & 343 & 2401 & 117649 \\
\hline 3 & 40 & 1 & 40 & 1600 & 1600 \\
\hline & $\sum$ & 10 & 483 & 6501 & 129249 \\
\hline
\end{tabular}

$\operatorname{Mean}(\bar{x})=\sum \frac{f x}{N}=\frac{483}{10}=48.3$

$\operatorname{Varian}\left(S^{2}\right)=\frac{n \sum f x^{2}-\left(\sum f x\right)^{2}}{n(n-1)}=$

$\frac{10(129249)-(483)^{2}}{10 \times 9}=11.76$

Standard Deviation $(\mathrm{SD})=\sqrt{ } \mathrm{S}^{2}=\sqrt{ } 11.76=3.42$

Modus $(\mathrm{Mo})=49$

Normality test $(\mathrm{Km})=\frac{\bar{x}-M o}{S}=\frac{48.3-49}{3.42}=-0.2$ Normal distribution of data for value $\mathrm{Km}=-0.2 \mathrm{~s}$ located in reception area $-1 \leq \mathrm{Km} \leq 1$.

To determine the interpretation of the level of consumer desires of achievement scores obtained from the value of questionnaire data vendors machine user of grated coconut are required in order to interpret the results of the assessment with a score value (n) the average number of samples 48.3 and $(\mathrm{N})$ total score of base 60 , then percentage of calculation process are :

$\mathrm{P}=\frac{n}{N} \times 100 \%$

then :

$\mathrm{P}=\frac{48.3}{60} \times 100 \%=80.5 \%$

Data generated from the questionnaires contains with the calculation of the distribution table, frequency scores traders questionnaire data. Afterward, it found a calculation of Mean=48.3, Varian $=11.76$, standard deviation $=3.42$, mode $=49,=-0.2$ and normality test interpersentase score level consumer desire with the score value achieved was $80.5 \%$.

From the instrument data, the interpretation value questionnaire scores, it was reached a score of $80.5 \%$. It can be matched with a conversion table in the form of a graduated scale model of which is contained in Table 1 by weight 4 results definition "Strongly Agree". Where the scores achieved are in the range of $76 \%-100 \%$ criteria.

Therefore, it can be concluded that for an assessment based on an overall assessment criteria for the desires of consumers (district OI) to the problems that exist "Strongly Agree" to undertake a development of the engine multipurpose grater.

\section{Conclusion}

From the discussion, it can be concluded that the priority consumers are very stressed to do a modification component or an additional tool in the machine grater multipurpose namely Cover Safeguard Fant Belt, Exhaust, Priority Motor Driving Fuel Gasoline, layout position Mover, Motor Starter, Plastic cleaning brush Roll Grate, and Plate Cap.

The conclusion is based on data obtained through questionnaires, and supported by observation and open interviews. Conclusions is generated from the data within the desires and expectations of consumers as user's grater multipurpose machine. The results of this study is expected to enhance an action of development to create new innovations using the latest ideas in optimizing the function of the multipurpose grater engine.

\section{References}

1. Annappa, C., \& Panditrao, K. (2013).. IJITEE, 2(6), 2278-3075.

2. Bernal, L., Dornberger, U., Suvelza, A., \& Byrnes, T. Report Universitat Leipzig. (2009).

3. German, M., Mengoni, M., \& Peruzzini, M. Computers in Industry 63, 12-29 (2012)

4. Jen, C., Cheng, Y., Shen, H., \& Yeong, L. ICEE2004/Proceedings/Papers (2015)

5. Jia, G., \& Bai, M. (2011). Computers \& Industrial Engineering 60, 445-454.

6. Kuo, H. A. (2011). ICIC International, 7, 253-268.

7. Lam, J. Transportation Research Part E., (2014).

8. Na, L., Xiaofei, S., Yang, W., \& Ming, Z. International Conference on Complexity Science and Information Engineering, 243 - 251. (2012).

9. Nukman. Jurnal Rekayasa Sriwijaya, Vol. VI, No. 1, April (1999).

10. Oke, S. Literature Review and Future Trends. DOI, 17(3) (2013)

11. Pattola, A. Indonesian Patent No. 10333. (1988)

12. Rajesha, G., \& Malliga, P. Proceedings International Conference On Design and MAnufacturing IConDM 2013), 1283 - 1292. (2013).

13. Sapuan, S., \& Mansor, M. Materials and Design 58, 161-167 (2014).

14. Sudiharto, P. Oration (2009).

15. Tian, Y. Report. Aalto University. (2011)

16. Tunggal, A. Report PT Rineka Cipta. (1998)

17. Yilmaz, H. Thesis ed. Izmir Institute of Technology. (2009)

18. Zarei, M., Fakhrzad, M. B., \& Paghaleh, M. J. Journal of Food Engineering, 25-33. (2011)

19. Luigi T. De Luca, Propulsion physics (EDP Sciences, Les Ulis (2009)

20. F. De Lillo, F. Cecconi, G. Lacorata, A. Vulpiani, EPL, 84 (2008) 